\title{
ESTIMATION OF TOLERANCE OF A DOMESTIC NON-STEROID ANTI- INFLAMMATORY DRUG IN THE POSTOPERATIVE PERIOD OF EXTRACTION OF CATARACTS
}

Estimation of tolerance of a domestic non-steroid anti-inflammatory drug in the postoperative period of extraction of cataracts

F. Bakhritdinova, K. I. Narzikulova Kumri Islamovna, Sh. A. Yusupov, M. E. Egamberdieva

Tashkent Medical Academy, Uzbekistan e-mail: shuchrat_66@mail.ru

Summary. The article discusses the efficacy and tolerability of a non-steroidal anti-inflammatory domestic drug after cataract extraction, the severit $y$ of side effects of a non-steroidal anti-inflammatory drug.

The aim of the study - optimization of methods of postoperative treatment of cataracts using the domestic non-steroidal anti-inflammatory Diclofenac drug, $0.1 \%$ eye drops, produced by JV "Jurabek Laboratories" LLC.

Materials and Methods. The study included patients who were at inpatient treatment at the Clinic No. 2 of the Tashkent Medical Academy. The study group included 60 people: 21 men and 39 women, the age of patients was 18-73 years. In two groups, we compared the efficacy and tolerability of domestic and foreign NSAIDs after cataract extraction.

Results. The effectiveness of the complex treatment is confirmed by the reduction in the duration of relief of the main symptoms of inflammation in patients of both groups. Both drugs did not cause side effects and were well tolerated by patients. Tolerability of the treatment in the group receiving domestic NSAIDs was $93.4 \%$, in the group receiving foreign NSAIDS - $95.7 \%$.

Conclusions. According to the results of our studies, it was proved that therapy after cataract extraction with the use of a domestic-made NSAID is not inferior in efficiency and tolerability to a foreign-made drug and can be used in the postoperative period of cataract.

Key words: cataract; non-steroidal anti-inflammatory drug; tolerance of non-steroidal anti-inflammatory drug; side effects of non-steroidal anti-inflammatory drug.
Переносимості вітчизняного нестероїдного протизапального препарату в післяопераційному періоді екстракції катаракати

Ф. Бахрітдінова, К. І. Нарзікулова Кумру Ісламовна, Ш. А. Юсупов, М. Е. Егамбердіева

Ташкентська медична академія, Узбекистан

Резюме. У статmі розглянуто питання ефрективності та переносимості вітчизняного нестероїдного протизапального засобу (НПЗ3) після екстракції катаракти, а також вираження його побічних ефектів.

Мета дослідження - оптимізувати методи післяопераційного лікування катаракти з використанням вітчизняного нестероїдного протизапального препарату «Диклофенак", 0,1\% краплі очні виробництва СП TOB «Jurabek Laboratories».

Матеріали і методи. У дослідження були включені пацієнти, які перебували на стаціонарному лікуванні на базі 2 клініки Ташкентської медичної академії. До групи дослідження було включено 60 осіб: 21 чоловік і 39 жінок, вік хворих становив 18-73 роки. У двох групах ми порівнювали ефрективність і переносимість вітчизняного і зарубіжного НПЗЗ після екстракції катаракти.

Результати. Ефрективність комплексного лікування підтверджена скороченням термінів зникнення основних симптомів запалення у пацієнтів обох груп. Обидва препарати не викликали побічних дій і добре переносилися пацієнтами. Переносимість проведеного лікування у групі, яка отримувала вітчизняний НП33, склала 93,4 \%, а у групі, що отримувала НПЗП зарубіжного виробництва, - 95,7\%.

Висновки. За результатами проведених досліджень доведено, що терапія після екстракції катаракти із застосуванням препарату НПЗЗ вітчизняного виробництва не поступається за ефективністю $i$ переносимістю препарату зарубіжного виробництва й може застосовуватися в післяопераційному періоді лікування катаракти.

Ключові слова: катаракта; нестероїдний протизапальний препарат; переносимість нестероїдного протизапального препарату; побічні ефекти нестероїдного протизапального препарату. 


\section{INTRODUCTION}

Cataracts, a clouding of the lens, is the leading cause of blindness in developing countries. Cataract surgery is recognized by the World Health Organization as the only fully rehabilitating operation among all surgical interventions.

The main goal of therapy after cataract extraction is to prevent complications, determine the cause of postoperative inflammation, maintain a normal level of patient activity and improve the quality of life $[1,2]$.

Cataract extraction is a surgical procedure to remove the lens of an eye that has become cloudy over time, impairing vision in that eye. This is part of a cataract surgery in which the removed lens is replaced with an artificial lens. The normal lens of the eye is clear and transparent, over time the lens becomes cloudy and vision becomes blurry as protein deposits accumulate on it, causing cataracts. Before cataract surgery, patients are usually given local anesthesia with eye drops or injection, and are often given additional medication to help the patient relax. An eye doctor (ophthalmologist) uses a special microscope to examine the eye. A shallow incision is made in the eye through which the lens is removed. Depending on the type of cataract, the surgeon may use sound waves to break the cataract into small pieces that will be sucked out of the eye through the incision; instrument for cataract removal in one piece with a large incision; or a laser to make incisions and soften the cataract before sucking it out. Using a laser instead of a scalpel can provide a more accurate cut and shorten recovery time. After removing the lens, the doctor replaces it with a clear lens called an intraocular lens and then closes the incision. The operation usually takes less than 30 minutes $[3,4,9]$. Using a laser instead of a scalpel can provide a more accurate cut and shorten recovery time. After removing the lens, the doctor replaces it with a clear lens called an intraocular lens and then closes the incision. The operation usually takes less than 30 minutes $[3,4,9]$. Using a laser instead of a scalpel can provide a more accurate cut and shorten recovery time. After removing the lens, the doctor replaces it with a clear lens called an intraocular lens and then closes the incision. The operation usually takes less than 30 minutes $[3,4,9]$.

We evaluated the effectiveness of Diclofenac, $0.1 \%$ $5 \mathrm{ml}$ eye drops, produced by JV LLC "Jurabek
Laboratories", after cataract extraction. Traditionally, drugs are selected based on controlled clinical trials.

Diclofenac is a proven, commonly prescribed nonsteroidal anti-inflammatory drug (NSAID) that has analgesic, anti-inflammatory and antipyretic properties and has been shown to be effective in the treatment of a variety of acute and chronic pain and inflammatory conditions. Like all NSAIDs, diclofenac exerts its action through inhibition of prostaglandin synthesis by inhibiting cyclooxygenase-1 (COX-1) and cyclooxygenase-2 (COX-2) with relative equipotency. However, extensive research shows that the pharmacological activity of Diclofenac goes beyond COX inhibition and includes multimodal and, in some cases, novel mechanisms of action. Diclofenac reduces eye inflammation, pain and discomfort in the eye (photophobia, burning, tingling, etc.) that can result from infection,

The aim of the study - optimization of methods of postoperative treatment of cataracts using the domestic non-steroidal anti-inflammatory drug Diclofenac, $0.1 \%$ eye drops, produced by JV "Jurabek Laboratories" LLC.

\section{MATERIALS AND METHODS}

The study included patients who were at inpatient treatment at the Clinic No. 2 of the Tashkent Medical Academy. The study group included 60 people: 21 men and 39 women, the age of the patients was 18-73 years.

Group 1 included 30 patients -18 women and 12 men aged 19-57 (average age $(34.6+0.1)$ years). Group 2 included 30 patients -21 women and 9 men aged 19-43 (average age $(32.5+0.1)$ years) (Table 1).

Depending on the therapy, the patients were divided into 2 homogeneous groups: 30 patients each. Patients of the control group in the postoperative period were prescribed NSAID of foreign production Diclofenac ophthalmic $0.1 \%$ eye drops, $5 \mathrm{ml}$, manufactured by CJSC "Liquor", Armenia, 2 drops 4 times a day. In the main group of patients, NSAID of domestic production Diclofenac $0.1 \% 5 \mathrm{ml}$ was prescribed - eye drops, produced by JV "Jurabek Laboratories" LLC, Uzbekistan, 2 drops 4 times a day. All patients, in addition to the above drugs, were prescribed antibiotic therapy. The treatment was carried out for 10 days.

Table 1. Characteristics of research groups

\begin{tabular}{l|l|l}
\hline \multicolumn{1}{c|}{ Distribution of patients } & \multicolumn{1}{c}{ Study drug } & \multicolumn{1}{c}{ Comparison drug } \\
\hline By gender & Number of patients & Number of patients \\
\hline Men & 12 & 9 \\
\hline Women & 18 & 21 \\
\hline Total: & $\mathbf{3 0}$ & $\mathbf{3 0}$ \\
\hline By age & Average age & Average age \\
\hline Men & 37.0 & 30.6 \\
\hline Women & 33.1 & 33.2 \\
\hline
\end{tabular}


The severity of side effects is assessed on a 4-point scale:

0 points - no side effects (well tolerated);

1 point - light side effects (well tolerated);

2 points - moderate side effects (tolerated satisfactorily);

3 points - side effects are pronounced (poorly tolerated).

4 points - severe side effects (very poorly tolerated)

\section{RESULTS AND DISCUSSION}

In the postoperative period, the objective symptoms were: injection of the vessels of the conjunctiva and sclera, conjunctival edema and unexpressed lacrimation.

The tolerability of the drug was assessed according to the following subjective data: burning sensation and tingling sensation when instilled, short-term blurred vision. In the main group, in which the patients were instilled with Diclofenac, $0.1 \% 5 \mathrm{ml}$ eye drops, produced by JV LLC "Jurabek Laboratories", Uzbekistan, burning sensation during instillation was observed in varying degrees in all patients (100\%), short-term blurred vision in $20 \%$ of patients. In the comparison group, in which the patients were instilled with Diclofenac Ophthalmic $0.1 \%$ eye drops, $5 \mathrm{ml}$, produced by CJSC "Likvor", Armenia, a burning sensation was also observed in varying degrees in all patients $(100 \%)$, short-term blurred vision was observed in $6 \%$ of patients.

Tolerability of the ongoing treatment in the group receiving Diclofenac, $0.1 \% 5 \mathrm{ml}$ (eye drops, produced by JV LLC "Jurabek Laboratories", Uzbekistan) was assessed as high $93.4 \%$. and $96.7 \%$, respectively (Table 2).

The effectiveness of the complex treatment is confirmed by the shortening of the time for relief of the main symptoms of inflammation in patients of both groups. Subjective improvement in the condition of the eyes in patients of the main and control groups was noted already on the next day from the start of treatment. On day 3 of treatment, there was a positive trend in all objective parameters: the cessation of lacrimation was noted, there was no edema, injection of the vessels of the conjunctiva and sclera: in $100 \%$ in the control group and 96.7 $\%$ in the main group.

Both drugs did not cause side effects and were well tolerated by patients. Only $20 \%$ of patients in the main group and $16 \%$ of patients in the control group had a short-term burning sensation, which subsided within 1 minute. Tolerability of the treatment in the group receiving domestic NSAIDs was $93.4 \%$, in the group receiving foreign NSAIDs $-95.7 \%$.

Table 2. Evaluation of efficacy and tolerability in patients of both groups in \% ratio (n-number of patients)

\begin{tabular}{l|l|l|c|c|c|c|c|c|c|c}
\hline Estimated indicators & \multicolumn{9}{|c|}{ Main group } & \multicolumn{5}{c}{ Comparison group } \\
\hline Score & 0 & 1 & 2 & 3 & 4 & 0 & 1 & 2 & 3 & 4 \\
\hline Portability in\% & 0 & 0 & $\begin{array}{c}6.6 \\
\mathrm{n}=2\end{array}$ & $\begin{array}{c}93.4 \\
\mathrm{n}=28\end{array}$ & 0 & 0 & 0 & 3.3 & $\begin{array}{c}96.7 \\
\mathrm{n}=1\end{array}$ & 0 \\
$\mathrm{n}=28$ & & \\
\hline
\end{tabular}

\section{CONCLUSIONS}

According to the results of our studies, it was proved that therapy after cataract extraction with the use of a domestic-made NSAID is not inferior in efficiency and tolerability to a foreign-made drug and can be used in the postoperative period of cataract.

\section{LITERATURE}

1. Akhuja M. Penetration of diclofenac through the cornea from oil droplets in vitro / M. Akhuja, S. K. Sharma, D. K. Majumdar // Yakugaku Zasshi. - 2007. - Vol. 127. - P. 1739-1745.

2. Percutaneous penetration of diclofenac and topical piroxicam / P. Van der Beil, A. D. van Eyck, H. I. Seyfarth [et al.] // J. Appl. Res. - 2003. - Vol. 3. - P. 505-511.

3. Prevention of macular edema in cataract phacoemulsification / I. E. Ioshin, A. I. Tolchinskaya, Yu. Yu. Kalinnikov, A. A. Ozderbaeva // Russian Ophthalmological Journal. 2014. - Vol. 2. - P. 21-26.

4. Koroleva I. A. Heading: Ophthalmology / I. A. Koroleva, E. A. Egorov // RMJ "Clinical Ophthalmology". - 2018. Vol. 4. - P. 194-198 DOI: 10.21689 / 2311-7729-2018-184-194-198.

5. Kim S. J. Non-steroidal anti-inflammatory drugs in ophthalmology / S. J. Kim, A. J. Flach, L. M. Jampol // Surv. Ophthalmol. - 2010. - Vol. 55. - P. 108-133.
6. Prevention of macular inflammation and edema after cataract with steroid and non-steroidal anti-inflammatory eye drops; systematic review / L. Kessel, B. Tendal, K. J. Jørgensen [et al.] // Ophthalmology. - 2014. - Vol. 121. - P. 1915-1924.

7. Mishima S. Pathophysiology and pharmacology of intraocular surgery / S. Mishima, T. Tanishima, K. Masuda // Aust. NZJ Ophthalmol. - 1985. - Vol. 13. - P. 147-158.

8. Flach A. J. Topical non-steroidal anti-inflammatory drugs in ophthalmology / Int. Ophthalmol. Clin. - 2002. Vol. 42. - P. 1-11.

9. Hashemi H. Small pupil and cataract surgery / H. Hashemi, M. A. Seidian, M. Mohammadpur // Curr. Opin. Ophthalmol. - 2015. - Vol. 26. - P. 3-9.

10. Shalnus R. Actual non-steroidal anti-inflammatory therapy in ophthalmology / R. Shalnus // Ophthalmologica. - 2003. - Vol. 217. - P. 89-98. 


\section{REFERENCES}

1. Akhuja M, Sharma SK, Majumdar DK. Penetration of diclofenac through the cornea from oil droplets in vitro. Yakugaku Zasshi. 2007;127: 1739-45.

2. Van der Beil P, van Eyck AD, Seyfarth HI, Viljoen I, Jooste M. Percutaneous penetration of diclofenac and topical piroxicam. J Appl Res. 2003;3: 505-11.

3. Ioshin IE, Tolchinskaya Al, Kalinnikov YuYu, Ozderbaeva AA. Prevention of macular edema in cataract phacoemulsification. Russian Ophthalmological Journal. 2014;2: 21-6.

4. Koroleva IA, Egorov EA. Heading: Ophthalmology. RMJ "Clinical Ophthalmology". 2018;4: 194-8 DOI: 10.21689 / 2311-7729-2018-18-4-194-198.

5. Kim SJ, Flach AJ, Jampol LM. Non-steroidal antiinflammatory drugs in ophthalmology. Surv Ophthalmol. 2010;55: 108-33.
6. Kessel L, Tendal B, Jørgensen KJ. Prevention of macular inflammation and edema after cataract with steroid and non-steroidal anti-inflammatory eye drops; systematic review. Ophthalmology. 2014;121: 1915-24.

7. Mishima S, Tanishima T, Masuda K. Pathophysiology and pharmacology of intraocular surgery. Aust NZJ Ophthalmol. 1985;13: 147-58.

8. Flach AJ. Topical non-steroidal anti-inflammatory drugs in ophthalmology. Int Ophthalmol Clin. 2002;42: 1-11.

9. Hashemi H, Seidian MA, Mohammadpur M. Small pupil and cataract surgery. Curr Opin Ophthalmol. 2015;26: 3-9.

10. Shalnus R. Actual non-steroidal anti-inflammatory therapy in ophthalmology. Ophthalmologica. 2003;217: 89-98.

Received 05.03.21 